\title{
The Construction of Event by the Media: A Study of Actors and Symbolic Landmarks in the Cases of Train Accidents in Yaoundé and Cameroonian President's Holidays in La Baule in 2009
}

\author{
Celestin Messanga Obama ${ }^{1}$ \\ ${ }^{1}$ Department of Advertisement/Advance School of Mass Communication, University of Yaoundé 2, Cameroon \\ Correspondence: Celestin Messanga Obama, Department of Advertisement/Advance School of Mass Communication, \\ University of Yaoundé 2, Cameroon.
}

Received: May 9, 2016 Accepted: May 17, 2016 Online Published: October 17, 2016

doi:10.11114/smc.v4i2.1927 URL: http://dx.doi.org/10.11114/smc.v4i2.1927

\begin{abstract}
Two types of facts, of different nature in the public life in Cameroon, have been considered as events. They are, on the one hand, the train accidents that occurred on 28 and 29 August in Yaoundé, and on the other hand, the cost of Cameroonian President Paul Biya's holidays in la Baule in France, from the 15th August to the 05th September 2009. In the first case, the subject is a spectacular and geographically close fact whereas in the second case, they are non-material and distant facts, having no spectacular character, rather on the symbolic value. This article shows that the event is neither constituted by a specific symbolism intrinsically related to a particular fact, nor by the spectacular aspect of the latter. It is a matter of aggregation of multiple facts which, placed around a central fact, take a precise meaning and give the central fact the dimension of an event. It is a construct that brings together in a narrative spine, symbolic homologies, memory effects and the culture of a given interpretative community.
\end{abstract}

Keywords: event, commonplace situation, importance, scarcity, co-construction

\section{Introduction}

According to the commonly-used definition, the word event refers to three meanings. In the first case, it is understood as a fact to which comes a situation. In the same sense, the event takes the significance of result or outcome of a scene. The second meaning considers the event as what occurs and that has some importance to man. This second meaning covers material aspects (catastrophe, accident, tragedy, etc...) as well as psychological aspects (luck, misfortune, conjuncture, business, history, etc.). The third meaning, drawing from statistics, attributes to the event, the significance of possible results or possibility. In a more general framework, event in this third sense can mean a test or experience.

Let's leave this third meaning and concentrate only on the first two. In the first case, there is a reference to the word "fact" and in the second one, an allusion to the expression " what happens ». According to Jürgen Habermas (1987), "a fact is the state of things that occur". However, it is understood that an event is basically a fact that is different from others by its importance. If by principle, facts are abundant, important facts on their own are rare. It appears that scarcity and importance are the essential characteristics of the event. By event, we shall therefore refer to a rare and particularly important fact. It is opposed to what will be convenient to call "commonplace situation". This dichotomy suggests that there exists, in their essence, on the one hand, important and rare facts, at the image of precious stones and, on the other hand, commonplace and abundant facts identifiable to ordinary stones, commonplace stones in a manner of speaking. This analogy allows the perception of the ontological existence of events and ordinary facts which are recognisable anywhere by everybody. But, if scarcity can be appreciated even by the empirical measure of occurrences, what in fact determines importance? That is the central question which is going to orientate our analyses.

In a historical approach, an event that occurs, according to Arlette Farge (2002), is:

«..., a moment, a fragment of perceived reality which has no other unity than the name that is given to it. Its arrival in history $[\ldots]$ is immediately shared by those who receive it, see it, hear about it, announce it and then keep it in the memory ».

In this thought by Arlette Farge, expressions like "perceived reality", "the name that is given to it" and "shared by those who receive it" indicate the constructed nature of the event. We therefore postulate by way of hypothesis that the event 
is not a body constituted with an intrinsic importance; it is a matter of cultural co-construction of the media and the public, through a conjunction of sensory and symbolic aspects of a fact in a given context. In this perspective, the sensory aspect is the one that offers itself to the concern of the fact by senses whereas the symbolic aspect refers to the different cultural references that permit to give a meaning to a fact. Thus, it appears on the one hand that two phenomena, of opposed nature, can both answer to the definition of event, and in another case, a commonplace situation.

Our theoretical position is based on constructivism with a systemic approach. It will be a matter of following how memory effects (history), symbolic places where facts happen, the status of individuals who take those actions or those towards whom actions are oriented, the power issues (politics) etc. are intertwined in a discursive frame, putting in relation some facts by giving them an importance to constitute an event. We do not pretend to explore a virgin space. Eliséo Veron (1981)' Jean-Pierre Esquenazi (2002), Georges Auclair (1970) and other analysts of media discourse have examined the media discourse in the construction of various objects before us. In fact, according to Laurent-Charles Boyomo Assala (2009), the concept of event "has mobilized research in information and communication sciences all along its maturation". This assertion discloses the strong intellectual preoccupation on this subject. Jean-François Tetu (2009) laying the theoretical bases that permitted him to consider a media event in its intrinsic nature, distinguishes the latter from the historical and scientific one. We want to focus our reflection on the media event. For that purpose, Jean-François Tetu (Op. cit. Ibid) states that "the conditions under which a fact becomes an event are thus analyzed, specifically through the relationship between the media and the event". According to him, the analysis of media event must take in consideration three columns that are: period (Date), space (Location) and duration (The event is brief). According to our anthropological perspective, we would add the shared norms. The objective of this reflection is to identify the mechanism of construction of events. We want to bring to light, the co-constructive aspect in which the public and the media interact according to shared norms.

At the methodological level, we shall follow the processing given by four national daily to railway accidents at Obobogo and Etoudi quarters ( $28^{\text {th }}$ and $29^{\text {th }}$ August 2009) on the one hand, and President Paul Biya's visit to la Baule in France (from $15^{\text {th }}$ August to $5^{\text {th }}$ September 2009) on the other hand. The choice of these four daily newspapers is justified, on the one hand, by their recognition (the most regular and the most important in terms of circulation) and on the other hand, by their divergent editorial lines. They are qualitatively representative of the major editorial policies of the Cameroonian press. In fact, Cameroon Tribune is the government's voice, (right); Le Messager can be considered as the voice of the opposition (the left); Le Jour is classified as the expression of centre-right whereas Mutations shall be considered as the one of the centre-left. We will limit ourselves to the editions of our corpus, on the principle according to which the tone of a publication can only be in accordance with the general editorial line of the newspaper concerned. This grading could be discussed because it is not based on a true analysis of these newspapers over the long term.

Two dates have been retained for this observation. They are, $31^{\text {st }}$ August for the train accidents and $7^{\text {th }}$ September 2009 for the President Paul Biya's stay in la Baule. In Cameroon, the daily newspapers are published six days a week, from Monday to Saturday. Monday in this context, takes a particular importance as the first day of publication for the week. The two train accidents took place during the week-end; Monday $31^{\text {st }}$ August was for the four daily newspapers of our corpus, the first day of publication after the accidents, whereas $7^{\text {th }}$ September was the first Monday after the return of President Paul Biya home. It should be noted that, the Cameroonian Head of State's stay in la Baule, appeared on the media in France a week before, (on $27^{\text {th }}$ August 2009) but only took its importance in Cameroon after his return to Yaoundé on Saturday $5^{\text {th }}$ of September.

In general, we are in face of two types of facts of different natures; the train accidents can be considered as sensory, whereas President Paul Biya's stay in la Baule is being considered as matter relevant to the symbolic aspect. The daily newspapers have reserved for these two types of events a longer treatment in time but our stop over the two days retained, is enough to see how their discourse report on the event.

\section{The Media and the Event}

Many classifications have been proposed to the media by researchers in information and communication sciences. Francis Balle (2003) makes a distinction between three families of media: autonomous medias (books, newspapers, audio disks, videos or computer sciences); broadcast media (radio and television); and communication media (telephone, telegraphy, internet). We shall simply distinguish between interpersonal media and mass media and our interest is going to focus on this last category.

In either case, the professionalization of the mass media leads to the problem of content of messages (the news) transmitted. In fact, in the face of facts that occur, the priority of professionals of the mass media is going to focus on those which are likely to attract the attention of the greatest number of people (the public); this shall be referred to as events. If it is true that all the facts released through the mass media do not necessarily constitute events, we must, 
however admit that events, that are rare and particularly important facts, occupy a prominent place in media coverage.

The relationship between mass media and event is not obvious. In fact, a number of facts qualified as important by some communities escape media attention whereas some are important only because a great number of mass media talk about them at the same time. This observation shows that, in modern societies, the event is determined by the mass media. One of the questions resulting from that is to know if the mass media transmit facts accurately at the basis of events they release or if by contrast, they disguise them. The previous question is to know if events transmitted are the reflection of an ontological reality or if they are rather a construction that is a mounting.

Functionalist analyses focus on the role of mass media. Jean-Pierre Esquenazi notes to that effect;

We shall end this introduction by tackling one of the errors commonly made concerning the mass media. Its origin is found in the poor understanding of their representative role; the mass media could only distort or twist facts they report; they would be destined to voluntary alteration or not. This problem considerably reduces the relation that we have with them and can prevent us from dealing with the role they effectively play." (Op. Cit., 5)

There emerges from this statement that the power of the media is often assessed through their capacity to distort or to report facts accurately. Such posture results in a Manichean perception of the media with, on the one hand truthful media and on the other hand, liars. Eliseo Veron writes:

Social events are not objects that would be found ready-made somewhere in reality and that the media would let us know the properties and the avatars afterwards, with more or less fidelity. They exist only since the media make them. (Op. Cit., 7-8)

In this statement, the problem posed is no longer the one of fidelity, or in the contrary, the distortion in the media discourse in relation to the events that would be a kind of rigid corpses but the one of the nature of events that the medium report to us. Here, it is a matter of constructivist perspective that avoids functional analyses but that is interested in imaginary productions of the media. The statements of the two authors could be reflective of the debate that characterizes their relation to reality. The problem consequently is to know what, in some material or symbolic facts and not in others, constitute events. In the previous statement, EliseoVeron (Op. Cit.) situates the concept of event in the media communication context. Meanwhile, we can extend it to communication in general because the event exists not only in mediatized societies. In fact, even societies marked by direct communication without broadcasting technology experience non recurrent facts bearing a community importance. The passage of migratory grasshoppers (/āngādā/) among the Beti of Cameroon equatorial forest is an event. Those who were privileged to watch this spectacle, more than fifty years ago, continue to talk about it today as a feat of arm of which they are the heroes. Nevertheless, this phenomenon is commonplace in the Far-North region of the country where the appearance of these insects is recurrent.

Our constructivist posture admits that discourse productions are not the reflection of a rigid and uncreated reference reality; it is rather a question of social constructions based on culture. Although marked by a pragmatic approach, Jürgen Habermas (1987, 341) distinguishes perceptible reality that needs observation and the symbolically pre-organized one which needs comprehension. This concept of reality symbolically pre-organized shows that the collective imagination of a group functions on the basis of preexisting structures. In the same sense, Alfred Schütz (2008) talks about the "taken for granted" that he defines as anything that the group or interpretative community holds from the past and admits as evident or established truth. This principle is valid in science as well as in popular knowledge. The "taken for granted" enable one to admit a proposal, to reject another or to formulate a new one. By following this principle as mode of symbolic pre-structuration, we can examine how events are constructed.

\section{The Discourses on Train Accidents in Cameroon Newspapers}

Our observation is firstly going to be focused on the front page of the four daily newspapers chosen. It should be noted that in their functioning, the mass media publish in the front page only facts thought to be particularly important. By this principle, they succeed in creating importance to the facts that they publish, just by the fact of putting them in that symbolic space. Therefore we can consider as event, a fact that benefits from a processing in the front page of several newspapers during the same period. The four newspapers, selected in our sample, publish all on the front page, the two types of facts retained in our problem statement. The following table presents the distribution of articles relevant to the train accidents in Yaoundé. 
Table 1. Train accidents on 28th and 29th August 2009 in Yaoundé in Cameroon's newspapers

\begin{tabular}{|c|c|c|c|c|}
\hline & Cameroon tribune & Le Jour & Le Messager & Mutations \\
\hline Top title & $\begin{array}{l}\text { Yaounde's series of train } \\
\text { accidents }\end{array}$ & Camrail & $\begin{array}{l}\text { Black weekend in } \\
\text { Yaoundé }\end{array}$ & Transport \\
\hline Title & $\begin{array}{l}\text { The compassion of the Head } \\
\text { of State }\end{array}$ & $\begin{array}{l}\text { Black weekend in } \\
\text { Yaoundé }\end{array}$ & $\begin{array}{l}300 \text { victims } \\
\ldots\end{array}$ & $\begin{array}{l}\text { Black weekend in } \\
\text { Yaoundé }\end{array}$ \\
\hline & & $\begin{array}{l}\text { Two people die in the } \\
\text { explosion of a tank at }\end{array}$ & $\begin{array}{l}\text {-failing } \\
\text { protection; }\end{array}$ & $\begin{array}{l}\text { Two derailments } \\
\text { have caused the }\end{array}$ \\
\hline Lead & & $\begin{array}{l}\text { Obobogo. } \\
\text { Five people dead and } \\
275 \text { wounded in a } \\
\text { derailment at Etoudi }\end{array}$ & $\begin{array}{l}\text {-Camrail: Only a } \\
\text { heap of scrap? }\end{array}$ & $\begin{array}{l}\text { death of about ten } \\
\text { people on Friday } \\
\text { and Saturday, } \\
\text { whereas fire has } \\
\text { devastated part of } \\
\text { SHO market. }\end{array}$ \\
\hline
\end{tabular}

Source: The author

A close look this table enables one to notice that the two train accidents of Yaounde feature on the front page of these four daily newspapers despite the different editorial lines.

Cameroon tribune has succeeded in finding three other facts that deserve to feature in that symbolic space. They are the following topics:

- The replacement of the American company GLOBELEQ by the Chinese consortium SINOHYDRO for the construction of the Memve'ele hydroelectric dam in the South Region.

- The football tournament baptized "Festi-foot Paul Biya" at Dimako in the Eastern Region.

- The arrest of the former Managing Director of the SCDP (Société camerounaise des dépots pétroliers).

The addition of these three topics appears as strategic in the way that it tends to reduce the importance of the main topic. The three topics are hopeful and joyful contrarily to the accidents. However, if the addition of the other topics tends to reduce the importance of the train accidents, Cameroon tribune enhances the train accidents by promoting the political action of the Head of State. In fact, for this governmental daily, even if they are important, the two train accidents are risky facts which have given Cameroon's Head of State the opportunity to express his compassion to the victims. In the same logic, Cameroon tribune lays emphasis on the readiness of the reaction of national authorities. By adding other facts on the train accidents, this governmental newspaper builds a kind of mega-fact and contributes to their erection in events.

One of the three other daily newspapers, Mutations, associates in its front page another fact, the SHO market fire that is not mentioned by the two others. Contrarily to Cameroon tribune, the fact concerned is macabre, and gives an apocalyptic vision of the national situation. While Cameroon Tribune's strategy tends to reduce the importance of the main subject, all the three other daily newspapers reinforce it. It therefore appears as if, the two train accidents are the revelators of an oncoming disaster and by the way, these dailies contribute to the construction of the event. In fact, $L e$ Jour, Le Messager and Mutations use in the headlines, the same expression "black weekend in Yaounde" combining the two accidents concerned into one major fact. It is a pessimistic perception that also appears through the highlighting of the number of victims. Contrarily to the three others which hesitate to find the guilty parties, Le Messager clearly accuses civil protection which it qualifies as "failing" and Camrail (Cameroon Railway Company) is accused of not maintaining railways lines which, by this, would be nothing but "a heap of scrap."

Despite their different editorial lines, each of the dailies examined, converges on the central facts which are the accidents though with different objectives, either to reduce their importance (Cameroon Tribune) or to aggravate their perception (the three others). From this follows the iceberg effect which swells the facts at the base so as to constitute the event. This process is observed on the facts that we qualify as sensory which distinguish themselves through their spectacular aspect. What about the symbolic facts which are non-palpable?

\section{The Discourses on President Paul Biya's Holidays in Cameroon Newspapers}

Concerning the cost of President Paul Biya's holidays in la Baule, the process is the same. The four daily newspapers give the same importance to the question despite the diversity of points of view. The following table presents the front pages of the four daily newspapers of our corpus. 
Table 2. Paul Biya's stay in la Baule from 15 August to 05 September 2009

\begin{tabular}{|c|c|c|c|c|}
\hline & Cameroon Tribune & Le Jour & Le Messager & Mutations \\
\hline Top title & & $\begin{array}{l}\text { Paul Biya in la } \\
\text { Baule }\end{array}$ & $\begin{array}{l}\text { On holidays in } \\
\text { France }\end{array}$ & Governance \\
\hline Title & $\begin{array}{l}\text { From la Baule, Paul Biya } \\
\text { assesses his recent official } \\
\text { visit in France }\end{array}$ & $\begin{array}{l}600 \text { millions of } \\
\text { FCFA in a three } \\
\text { week holidays }\end{array}$ & $\begin{array}{l}\text { Biya blows close to } \\
28 \text { million of FC FA } \\
\text { a day P. } 2\end{array}$ & $\begin{array}{l}\text { Paul Biya and his } \\
\text { own folks' holidays } \\
\text { in billions in la } \\
\text { Baule. }\end{array}$ \\
\hline Lead & & $\begin{array}{l}\text { The cost to the } \\
\text { Cameroonian } \\
\text { taxpayer of the } \\
\text { current stay in } \\
\text { France. }\end{array}$ & & $\begin{array}{l}\text { The revelation is } \\
\text { made by French } \\
\text { newspapers. }\end{array}$ \\
\hline
\end{tabular}

\section{Source: The author}

Cameroon tribune finds no problem with President Paul Biya's visit to la Baule. On the contrary, it tackles it as a positive moment where the President conducts a diplomatic evaluation (and not a financial one) of his official visit to France. For Cameroon tribune, President Paul Biya's visit to la Baule is an event precisely because it permits Cameroon to consolidate its relations with France. By painting a picture of President Paul Biya's visit to la Baule as the occasion for Cameroon to consolidate its relations with France, Cameroon tribune gives a particular importance to this fact.

As in the previous case, Cameroon tribune's position differs from that of the other daily newspapers of our sample. In fact, for Le Jour, it is a costly visit for the Cameroonian taxpayer. It is the same perception that appears through the expression "Biya blows close to 28 million per day" used by Le Messager. In choosing as top title "Governance", Mutations suggests that President Paul Biya's expenditures during his visit in la Baule constitute a problem of governance. These three dailies build the idea that the wellbeing of Cameroonians is mortgaged by the expenditure linked to this stay, and this gives it, by the way, a particular importance.

In total, despite the divergence of their editorial lines, the four daily newspapers of our corpus consider the Yaoundé train accidents and President Paul Biya's stay in la Baule as important facts, therefore as events. What can be the cultural frames that enable each of the four daily newspapers to give importance to these facts? To answer that question, we are going to analyze in our anthropological posture, the acting as well as the place of expression to see how the symbolism associated to it, permits the production of values identified.

\section{The Actors and the Symbolic Places of Expression}

The event is constituted by a constellation of close facts and a narrative chain. It is, as Jean-Pierre Esquenazi (Op. Cit. 78) says, a configuration inside which a fact becomes intelligible when "it comes into close contact with other facts, each of these shaping a link in the narrative chain that links them." It may happen that the central fact no longer plays the main role in that constellation; the importance is therefore given to peripheral facts which become the center of the event. Michel Foucault (1969) reveals that actors involved in facts that occur and the places where these facts take place, play an significant role in the importance given to these facts. For the two types of facts that interest us, let's analyze the acting and the symbolism around the places where they happen.

In the case of train accidents, Obobogo's derailment on $28^{\text {th }}$ August can be considered as the central fact, the second one (Etoudi), in the neighborhood of Cameroon's presidency, just having an aggravating effect on it. This main accident is composed of the reversal of wagons carrying fuel, the explosion of tanks, fire, cut rails, dead people etc. Here, we are dealing with distinct facts whose cohesion in one unique event depends on the narrative chain.

For Cameroon tribune, "...tanks of oil products leave the track and catch fire: two people dead. » p. 7. The logic underlying this statement implies that the fire is generated by the derailment of wagons carrying oil products, the two dead people being perceived as the consequence of the conjunction of the derailment and the fire. Cameroon tribune's report does not tackle the causes of these facts which thus appear as a random result. It is a narrative choice that can only be explained through the status of the actor of that narration. In fact, Cameroon tribune is the government's organ of expression. In its functioning, the government that is charged with the security of citizens is concerned with reassuring them and to show that it plays that role very well. This explains why Cameroon tribune lays emphasis on the Head of State's compassion and the "rapid mobilization" of the government, administrative authorities and forces of law and order (p. 11). These sub-facts are not intrinsically linked to the derailment but they appear in this discourse as parts of the accident. The Head of State's compassion added by this daily newspaper gives a national dimension to the fact and raises it to the dimension of event. This is made possible because of the symbolic aspect of the actors concerned (Head of State, members of government, administrative authorities, etc.). A train accident without all this mobilization would have been considered as common place fact. 
In their mode of construction of reality, the mass media superimpose their discourses on those of another type of actors who are their sources. The choice of those sources is also pre-structured. It is orientated by the editorial policy of the media. In this present case, they are: Hamadou Sali, the Chairman of the Board of Directors of Camrail and Issa Tchiroma, the Minister of Communication, government spokesman. However these two actors were not present where the drama unfolded at the time the facts occurred. They are chosen on the basis of their social status (Board chairman and Minister). These statuses, for this daily newspaper give credibility to the statements published. In fact, it is generally admitted in journalistic practice that the authority possesses a network of reliable information free from error. The choice of the editorial policy other witnesses of Cameroon tribune remains defined by the general logic of its discourse. For Merlin, a student at Obobogo, "firefighters arrived promptly at the accident scene". Nadine Ateh, a student at Obobogo said that the Mayor had mobilized the nearby residents; Soumaila, a student at Obobogo said on his own that "the accident happened in a risky area". Only Anatole, a tile fixer at Obobogo revealed something that suggested the failure of Camrail's managers. He said there was a portion of one meter of rails that was broken and despite the warnings of the nearby residents, no measure had been taken. The second type of sources is not socially important but it is taken in consideration because of the agreement between its testimony and the one of the first type; it confirms the postulate of identity of views between the authorities and the common people.

The discourse of the other daily newspapers does obey the same principles despite the difference of editorial policies. Le Messager with the reinforcement of pictures announces in the front page a black weekend in Yaoundé, adds in page 3 that the hecatomb was avoidable, suggesting that the government had failed in its role of protecting the people. In page 4, Le Messager titles: "Camrail in the dock" and below (page 5), it involves: government members, the Government Delegate of the Yaoundé Urban Council and the forces of law and order. Contrarily to Cameroon tribune that gives the perception that these actors work for the general interest and that they are working well, Le Messager suggests the contrary. Instead of making them talk, it talks about them. Readers are informed that the Minister of Public Health, worried about his residence situated in the vicinity of the accident, was forced to abandon his car to run on foot in order to secure his residence. For this newspaper, it is said that the Government Delegate of the Yaounde Urban Council did not have the courage to go closer to the scene of the accident because he was afraid of flames. Having not approached the facts, these different authorities are said to have given wrong information to the press. Talking about the forces of law and order, Le Messager wonders if they are trained only to subdue the populations, a way of saying that they were unable to control the fire. In the same way, it shall be retained from the reading of Le Messager that government action was limited to meetings and visits that could be regarded as parades.

Like Cameroon tribune, Le Messager gives the floor to four witnesses. According to Yves Roland Amougou, former employee of REGIFERCAM (The former Cameroon National Railway Company), the accidents are caused by the fact that the State does not want to follow the new trends in technology. According to Martial O. a railway worker executive at Belabo railways station, "it is the consequence of a mismanaged privatization." Salomon Ewon, a resident: "it's God's anger on Cameroon". Guy M. a student at the University of Yaoundé2: "by thirst of power, innocent lives are sacrificed ". Facts like privatization, new technology trend and religious practices highlighted here are not part of the accident; they give another dimension to it. All these declarations make people think that the train accidents of 28 and 29 August are the result of incompetence and magical practices of Cameroonian authorities, a position that goes to the far side of the earth of the one of Cameroon tribune. From the same events, it appears two opposed perceptions: an optimistic one, the one of Cameroon tribune and another, pessimistic, the one of Le Messager.

Mutations shows the readiness and the efficiency of government's action, a position that is close to the one of Cameroon tribune. Like the latter, Mutations gives the floor to a witness who declares that "the railway line was cut". The difference between the words used by the witnesses ("broken" by Cameroon tribune and "cut" by Mutations) is not unwarranted. Mutation's version make people think on the one hand that the derailment was caused by an action of sabotage and on the other hand that government has not been vigilant enough to counteract these actions of sabotage; a position that Cameroon tribune cannot defend. Meanwhile, Mutations gives the floor to the Managing Director of Camrail (page 11) who declares that there has been no sabotage. This debate on sabotage gives a political dimension to the accident and raises it to the status of event.

Le Jour, in relation to the accidents, has a balanced position. Like Cameroon Tribune, it gives the floor to the authorities and shows their actions on the field but the witnesses make people think that public action was not efficient. From the four witnesses, it can be concluded that it was possible to save the lives of the people who were dead.

The pessimistic presentation of the facts by these three daily newspapers permits the emergence of the idea of failure of government in the role of protecting the people and therefore builds the impression of common insecurity. Consequently the facts that reveal the feeling of common insecurity take a particular importance. The above analysis on sensorial facts shows that despite the different editorial lines, the procedure is the same. What about the symbolic facts? 
Concerning the cost of President Paul Biya's holidays in la Baule, the process looks the same. The central fact that can be retained is the presence of President Paul Biya in la Baule from15 August to 5 September 2009 with a delegation of more than 40 people. Beyond that central fact, we can retain as secondary ones: the reception offered in his honor by the City hall of la Baule, the discourse of French mass media (Ouest-France, France Inter and Radio Fidelité Nantes) on that stay, the releasing by the French government of a financial assistance to Cameroon in the same period.

It has appeared to us that Cameroon tribune's discourse is pre-structured by the postulate according to which government takes care of the citizen's interest and that it does it well. In this sense, this daily newspaper is going to find in the Cameroonian president's stay in la Baule the opportunity for him to reinforce the cooperation between Cameroon and France. The article on page 2 is titled: "From la Baule, President Paul Biya assesses his recent official visit to France". The lead is going to precise: "on the occasion of the reception offered on Friday 28 August in his honour by the City hall of la Baule, the Head of State was pleased about the large success of his recent official visit to France." Cameroon tribune appeals to the fact not directly linked to those which constitute the event concerned. It is President Paul Biya's official visit to Paris, before his private visit to la Baule. The bringing together here between those different facts suggests a positivist interpretation of President Paul Biya's visit to la Baule. That alloy makes people think that the President went to la Baule to assess his official visit to Paris. The result is that, even on holidays, the President works for the interest of the country. The reception offered by the City hall of la Baule hence appears as a diplomatic moment. Emphasis is laid on the presence during that reception of French economic operators seen as potential investors: "the flock put together for the circumstance at la Baule City hall was made of many economic operators among which hotel owners and tourism operators." As in the case of train accidents, it appears an optimistic perception of the event.

The mode of construction of discourse by Le Messager remains guided by pessimism. The top title sets the tune: "Cameroon-Presidency of the Republic, a waste" (p. 2). The lead continues: "Cameroonian president likes sea water therapy in la Baule. Estimated bill for three weeks of relaxation: close to three million euros". And the title continues: "Holidays: Biya spends 27300000 CFA francs per day". The content of the article estimates the expenditures of Cameroonian President above the ones of the French president Nicolas Sarkozy and American presidents Georges W. Bush and Barack Obama put together. Here, there is no allusion to the official visit to Paris. The reception offered by the Mayor of la Baule is presented as an expression of gratitude of the authorities of the city, for the generosity of President Paul Biya and his entourage: "the Mayor, as all the local traders appreciate those generous tourists who do not skimp on spending."

As in the case of train accidents, Le Messager's discourse is pessimistic. It makes people think that the authorities in place in Cameroon do not act in the direction of citizens' interests, but for their own interests. Although Le Messager's discourse is situated on the other side of the world of Cameroon tribune, it remains true that the two organs function on the basis of a number of editorial predispositions. These are underlined by their relation to the political power. Cameroon tribune is in the center of the power whereas Le Messager is at the periphery. The other daily newspapers occupy an intermediate position and can, in some aspects, come closer to one or another of these extreme models.

The position of Mutations comes closer to the one of Le Messager. Le Jour denounces the expenditures made, but mitigates the statement by comparing them to the expenditures made by the Senegalese president Abdoulaye Wade estimated at 725 million CFA francs, that is 125 million more than the ones of President Paul Biya. With time, news actors come into play, giving more and more to facts a particular symbolism. That is the entrance of political officials (CPDM executives, members of government, intellectuals, etc.) to "defend" President Paul Biya against what henceforth takes the sense of "political plot".

\section{The Surfaces of Emergence of Discourses}

According to Michel Foucault (Op. Cit.), surfaces of emergence can be understood as social and cultural domains on which subjects or themes appear in communication. The acting is not enough to understand the pre-structuration of the media discourse on the event; symbolism linked to circumstances that to the context should also be associated. Talking about the train accidents, some symbolic facts should be called upon. Obobogo is a quarter near Nsam where on 14 February 1998, there was a macabre fire caused by petroleum products. To that effect, Le Jour says: "women who have left their children at home are inconsolable. The spectre of Nsam 1998 is still hovering over (an explosion of a SCDP tank car in that quarter had killed close to 250 people").

The reference to that far event shows that old knowledge (experience) acts in the grasp of facts. Because the fire of the tanks had killed 250 people in 1998 in the same place, the actors-witnesses of the Obobogo accident make a transposition on the basis of those cultural achievements. Moreover, Le Messager expresses quite clearly that memory effect. "In the subconscious, people think of Nsam's disaster on 14 February 1998 because the train that has just derailed was carrying fuel."

Beyond the memory effect that establishes a homology with real facts, other types of associated facts contribute to the 
construction of the event. In the case of train accidents, the movement of firefighters, of political and administrative authorities as well as reactions of panic of neighboring populations are autonomous facts which, on the one hand have a symbolic connection only in relation with the fire of the derailed train, and on the other hand, contribute to give a particular symbolism to the fact, or better, to all the central facts (fire of the derailed train). The running of the neighbor is interpreted as a "reaction of panic" only when placed in the context of the accident. Similarly, the movements of the authorities, firefighters and other security bodies, the Red Cross and the officials of the railways company (Camrail) so different in the form and objectives, are perceived in a uniform manner as "mobilization" only when placed within the framework of accident. These underlying or collateral facts confer on the central fact a particular symbolism; they are aggravating facts that confer on the fire of the derailed wagons the status of event.

In the case of the cost of President Paul Biya's holidays in la Baule, we shall retain as peripheral facts: Cameroon's economic situation (highly indebted poor country); loans granted to Cameroon by France; fight for the consolidation of public finances in Cameroon known under the name "Sparrow hawk operation" and the presidential elections expected in 2011. They are isolated facts, distinct among them and distinct from the central fact that is the stay of the Cameroonian Head of State in la Baule. As in the case of train accidents, they take a precise significance, when a narrative chain brings them closer to the central fact. The narrative chain gives at the same time a particular symbolism to the central fact.

French mass media talk about President Paul Biya's stay in la Baule only because it appeared incongruous to them that the president of a highly indebted poor country should spend, for private reasons, more than the presidents of rich countries, hence the comparison with the holiday's expenditures of the French President and the two American Presidents. These are cultural achievements. In other words, if a Japanese Prime Minister had made such expenditure, the fact would have given way to banality. The cultural status of the French mass media as the "voice of the former guardian" is not neutral in the construction of this event. In fact, the observation of the relations between Cameroon and France permits to notice that what is said in France and precisely by French people has a particular echo in Cameroon. Many times, the national press has published information either on the possible fortune of President Paul Biya or his expenditures, and it did not raise a public debate.

By choosing as top title "Governance », Mutations is in keeping with the negative logic. The reference to the consolidation of public finances in Cameroon leads to putting President Paul Biya's expenditure in la Baule within that framework. Out of that context, the fact would have given way to banality. It should be noted that this "affair" is not woven on the first two travels of President Paul Biya to la Baule, but on the third. No doubt that the expenditures made during the first two visits in that city were not negligible, but the context differs.

The 2011 electoral stake is clearly mentioned by a witness who talks in Le Messager about the Obobogo accident: "the 2011 presidential elections are imminent and everybody wants to keep their place in the government. Follow my gaze..." (p.6). In the case of President Paul Biya's holidays in la Baule, this fact is not explicitly mentioned by any of the four daily newspaper, but it enables one to understand the significance that the cost of the Cameroonian President (future candidate) takes in la Baule. As in the cases of train accidents, it appears that the event is perceived only when it is situated in an interrelation of observable facts and the symbolic pre-structuration that gives a sense to the value given to those facts.

\section{Conclusion}

Our major worry was to discover what enables one to consider a fact or a group of facts as an event. Our hypothesis postulated that the cultural achievements of an interpretative community, which by granting a particular significance to some facts enable one to consider them as events. By following two types of events through four national daily newspapers, we have observed in the light of Eliseo Veron, Alfred Schütz, Jürgen Habermas and Michel Foucault that an event is a constellation of facts, often distant in space as well as in time, but that the knowledge acquired by the interpretative community that is its culture, brings together in a discourse, to give it a particular meaning. In this sense, the train accidents of 28 and 29 August in Yaoundé can be considered as events only when they are placed in the same perceptive frame with the victims, the nearby residents, the mobilization of the authorities, the memories of previous accidents and the future political stakes. Similarly, the third travel of President Paul Biya in la Baule in France can be considered as an event (unlike the first two fallen in anonymity) only if it is placed in a background of indebtedness, of fight for the stabilization of public finances and the eve of presidential elections, contexts underlined by the colonial memory of the relations between France and Cameroon. This result shows that facts are nothing in themselves, without a symbolic system shared by a given interpretative community. The event appears from that moment not as an existence in itself, but as a cultural construct. 


\section{References}

Arlette, F. (2002). Penser et définir l'événement en histoire, Terrain [En ligne], 38 | mars 2002, mis en ligne le 06 mars 2007, consulté le 17 mai 2016. URL : http://terrain.revues.org/1929 ; DOI : 10.4000/terrain.1929.

Auclair, G. (1970). Le Mana quotidien : structures et fonctions de la chronique des faits divers, Paris, Éd. Anthropos.

Balle, F. (2003). Médias et sociétés, Paris, Mont chrétien.

Boyomo, A. L. (2009). « SIC et Evènement » in Fréquence-Sud Nouvelle Série, N 20-Nov Yaoundé

Esquenazi, J. P. (2002). l'Ecriture de l'actualité, Grenoble, Presses Universitaires de Grenoble.

Foucault, M. (1969). L'archéologie du savoir, Paris, Gallimard.

Habermas, J. (1987). Logique des sciences sociales et autres essais, Paris, PUF.

Habermas, J. (1987). Logique des sciences sociales et autres essais, Paris, PUF

Schutz, A. (2008). Anne Noschis-Gilliéron ( trad), Le chercheur et le quotidien : phénoménologie des sciences sociales PARIS, Méridiens Klincksieck

Tetu, J. F. (2009). «De l'évènement aux affaires » in Fréquence-Sud Nouvelle Série, N 20-Nov 2009

Veron, E. (1981). Construire l'évènement : les médias et l'accident de three mile island, Paris, Les Editions de Minuit.

- Cameroun Tribune ${ }^{\circ} 9424 / 5625$ of 31 th august 2005

- Le jour $\mathrm{n}^{\circ} 519$ of 31 th august 2005

- Le Messager $\mathrm{n}^{\circ} 2930$ of 31 th august 2005

- Mutations $\mathrm{n}^{\circ} 2478$ of 31 th august 2005

\section{(c) $\mathbf{E Y}$}

This work is licensed under a Creative Commons Attribution 3.0 License. 